\title{
O que é religilão: $O$ caso da Nova Era
}

\author{
William Tomio Shinkai ${ }^{1}$
}

\section{Resumo}

O trabalho concerne na análise do conjunto de orientações ideológicas e práticas sociais definidas pelos atores nelas envolvidos como "místicas" ou "esotéricas" e conhecidas sob o nome geral de "Nova Era". Boa parte dos estudos de caráter antropológico a respeito dessas orientações e práticas as define como "religião", o que, frequentemente, contrasta com a autodefinição dos agentes.

O objeto de estudo é a Nova Era, um conjunto de orientações ideológicas e práticas sociais definidas pelos sujeitos como "místicas" ou "exotéricas". Na definição de José Guilherme Magnani

"A impressão inicial que se tem, quando se entra em contato com esse tema, é de que nele cabe qualquer coisa, de crença nos duendes a cerimônias xamânicas, da devoção aos anjos á rituais de bruxaria celta, de terapias inspiradas na medicina tradicional chinesa ou indiana a técnicas e meditação, do uso de cristais á música New Age." (MAGNANI, 2000: 7)

Todas essas práticas, num processo que se inicia no século XVII, são definidas em oposição à religião tida como "certa" (o cristianismo) e à compreensão "certa" da natureza (a ciência). Com efeito, este universo passou a ser considerado crendices e superstições, apesar de ter constituído historicamente uma forma de conhecimento legítima (é só pensar no papel da alquimia no desenvolvimento do pensamento científico), bem como uma

\footnotetext{
${ }_{1}$ Orientadora: Profa. Doutora Maria Cristina Pompa
} 
prática difundida no seio do próprio cristianismo (como no catolicismo popular).

Contudo, nas décadas de 1960 e 1970, ocorre a emergência desse conteúdo marginalizado pelo cristianismo oficial e pela ciência moderna, mas agora vinculado a uma nova experiência religiosa que se fundamenta na subjetividade.

Este revigoramento das práticas místico-esotéricas ocorre no período da chamada contra-cultura, período esse em que os jovens - especialmente nos Estados Unidos - buscavam novas experiências de vida, criticavam a tradição bíblica e a sociedade individualista. A busca por uma nova consciência como modo de vida faz com que surja na década de 1960 uma "nova espiritualidade", vista como uma nova "consciência religiosa".

A partir da revisão bibliografia, o trabalho acompanha a construção da "Nova Era" enquanto "religião" pelos diversos autores, analisando recortes teóricos e instrumentos metodológicos. A partir dai, realizo uma comparação entre discurso antropológico e discurso "nativo" para verificar convergência e divergências.

Como metodologia, foram realizadas etnografias em diversas feiras místicas na cidade de São Paulo, feiras que concentra uma gama de frequentadores que vão dos "místicos esotéricos" aos simples curiosos, observando a relação entre prática e discurso. Paralelamente, foi utilizado o método da entrevista e da história de vida, para compreender a trajetória pessoal e social dos freqüentadores.

Existe uma gama de autores que estudam a Nova Era no Brasil e no Exterior, mas privilegiei na minha revisão bibliográfica os autores José Magnani, Fátima Tavares, Sônia Maluf e Giovanni Filoramo pela relevância que possuem em suas produções acadêmicas. 
Cada autor tenta elaborar de maneiras diferentes um modelo metodológico capaz de abordar a complexidade do fenômeno na sociedade, pois a Nova Era, por possuir uma fluidez entre seus membros e não apresentar uma hierarquia institucionalizada, foge, em princípio, das características de senso comum sobre o que é uma religião. Este senso comum, grosso modo, compreende a religião como centralizadora de dogmas específicos, voltadas para uma verdade absoluta e possuindo um corpus doutrinário rígido.

$\mathrm{O}$ autor Magnani, preocupado em compreender o fenômeno social a partir da antropologia urbana, utiliza-se de conceitos como mancha, circuito e trajeto para compreender os padrões de comportamento presentes na cidade que formam um estilo de vida da Nova Era.

A autora Fátima Tavares salienta o processo de especialização apresentado pela terapêutica alternativa, onde se valoriza as técnicas de diagnóstico e cura, em busca de uma legitimação perante à medicina, como ocorreu com a homeopatia.

Já Maluf interpreta a nova era a partir de um denominador comum, que é a crise moral e física do individuo. A cura da crise é interpretada pelo individuo a partir da mudança do eu, pois a doença é originada a partir da desarmonia entre corpo, mente e espírito, sendo necessária uma condição de "despertar espiritual" e "consciência de si” para a realização da cura.

Por último, Filoramo diz não existir novas religiões, mas uma "refuncionalização de mensagens de salvação tradicionais", que são readaptadas a novas exigências socioculturais e espirituais emergentes. Atendendo assim, as necessidades do indivíduo e a atribuição do caráter universalista no fenômeno esotérico. 
As etnografias realizadas nas feiras místicas na cidade de São Paulo corroboraram parcialmente a interpretação da Nova Era elaborado pelos autores.

Foi possível observar nas feiras místicas o conceito de circuito apresentado por Magnani, já que o "nativo" expôs a sua apropriação de vários espaços que compõem a Nova Era, como centros integrados, centros especializados e pontos de venda.

Também observei o grande número de terapeutas holísticos que foram nas feiras com o intuito de assistirem as palestras e se atualizarem com o que existe de novo no meio terapêutico, aprimorando o conhecimento técnico que tiveram nos cursos que os legitimam como terapeutas alternativos, segundo Tavares.

Conversei com inúmeros frequentadores sobre o que os motivava a irem as feiras e as respostas em grande maioria foram relacionadas à crise moral ou física apontada por Maluf.

Como por exemplo, o caso da Marcilha, que foi na feira mística com o objetivo de ser atendida no Tarô, pois segundo seu médico, o problema circulatório em suas pernas causaria amputação das mesmas e a cigana ao dizer que sua saúde melhoraria, tirou uma angústia muito grande de que sentia.

Por último, observei o grande número de kardecistas e praticantes do candomblé e Umbanda nas feiras místicas. Seguindo Filoramo, podemos pensar que essas religiões tradicionais podem dispor o individuo de fragmentos simbólicos para compor seu novo repertorio simbólico na prática da Nova Era. 
Em conclusão, podemos afirmar o seguinte: a discussão sobre religião é extremamente complexa, por ser influenciada pela própria noção de religião construída no Ocidente. A grande tarefa das ciências sociais tem sido a de recuperar legitimidade de crenças e práticas consideradas até então ilegítimas, porque associadas à magia.

Neste sentido, compreende-se o termo "religião", usado pelos autores para definir a Nova Era. Por outro lado, os próprios "discursos nativos" dos participantes da Nova Era não parecem dar um grande relevo a esta definição, preferindo outras, como "fillosofia", "modo de vida", etc., justamente por reivindicar o lado marginalizado pela religião oficial e pela ciência: o da magia, da bruxaria, do conhecimento exotérico.

A etnografia e as entrevistas mostraram, finalmente, que o horizonte simbólico da Nova Era, assim como o das outras opções religiosas pelas quais os sujeitos transitam no Brasil contemporâneo, inclusive o catolicismo ou as seitas evangélicas, diz muito mais respeito a práticas do que a crenças. Os adeptos frequentadores, apesar da insistência na questão da espiritualidade (que parece se opor à materialidade), procuram soluções concretas para problemas concretos. (entendendo com isso até a própria desordem "espiritual" do mundo) e elaboram práticas de diagnóstico e de cura para solucionar estes problemas.

Isso constitui sem dúvida um problema para as ciências sociais. 